\title{
Determination of Folic Acid Using Biosensors-A Short Review of Recent Progress
}

\author{
Alessio Di Tinno ${ }^{1,2,+}$, Rocco Cancelliere ${ }^{1,3,+}$ and Laura Micheli ${ }^{1,4, * \text { (D }}$ \\ 1 Department of Chemical Sciences and Technologies, University of Rome Tor Vergata, Via della Ricerca \\ Scientifica 1, 00133 Rome, Italy; alessio.ditinno@alumni.uniroma2.it (A.D.T.); \\ rocco.cancelliere@uniroma2.it (R.C.) \\ 2 Department of Electrical and Information Engineering, University of Cassino and Southern Lazio, \\ Via Gaetano di Biaio 1, 03043 Cassino, Italy \\ 3 CNR-National Research Council of Italy, Institute of Crystallography (IC), Via Salaria Km 29,300, \\ 00015 Rome, Italy \\ 4 INBB - Consorzio Interuniversitario Istituto Nazionale di Biostrutture e Biosistemi, Viale Medaglie d'Oro 305, \\ 00136 Rome, Italy \\ * Correspondence: laura.micheli@uniroma2.it \\ + These authors contributed equally to this work.
}

Citation: Di Tinno, A.; Cancelliere, R.; Micheli, L. Determination of Folic Acid Using Biosensors-A Short Review of Recent Progress. Sensors 2021, 21, 3360. https://doi.org/ $10.3390 / \mathrm{s} 21103360$

Academic Editor: Antonio Guerrieri

Received: 31 March 2021

Accepted: 8 May 2021

Published: 12 May 2021

Publisher's Note: MDPI stays neutral with regard to jurisdictional claims in published maps and institutional affiliations.

Copyright: (c) 2021 by the authors. Licensee MDPI, Basel, Switzerland. This article is an open access article distributed under the terms and conditions of the Creative Commons Attribution (CC BY) license (https:// creativecommons.org/licenses/by/ $4.0 /)$.

\begin{abstract}
Folic acid (FA) is the synthetic surrogate of the essential B vitamin folate, alternatively named folacin, pteroylglutamic acid or vitamin $B_{9}$. FA is an electroactive compound that helps our body to create and keep our cells healthy: it acts as the main character in a variety of synthetic biological reactions such as the synthesis of purines, pyrimidine (thus being indirectly implied in DNA synthesis), fixing and methylation of DNA. Therefore, physiological folate deficiency may be responsible for severe degenerative conditions, including neural tube defects in developing embryos and megaloblastic anaemia at any age. Moreover, being a water-soluble molecule, it is constantly lost and has to be reintegrated daily; for this reason, FA supplements and food fortification are, nowadays, extremely diffused and well-established practices. Consequently, accurate, reliable and precise analytical techniques are needed to exactly determine FA concentration in various media. Thus, the aim of this review is to report on research papers of the past 5 years (2016-2020) dealing with rapid and low-cost electrochemical determination of FA in food or biological fluid samples.
\end{abstract}

Keywords: folic acid; real samples; analytical methods; electrochemical tools

\section{Introduction}

Folic acid (FA) or pteroylglutamic acid is a water-soluble B-complex vitamin and, due to its extremely important functions, represents an essential constituent of the human diet. It is the synthetic substitute of the essential B vitamin folate, also known as pteroylglutamic acid, folacin or vitamin B9. The IUPAC name of FA is (2S)-2-[[4-[(2-amino-4-oxo- $1 \mathrm{H}-$ pteridin-6-yl)methylamino]benzoyl]amino]pentanedioic acid.

Beginning in the 2000s, FA and folate derivatives received increasing interest due to their importance for human well-being and due to growing understanding of the consequences of deficiency [1,2]. These molecules are considered essential compounds, because precursors of fundamental coenzymes are needed in many crucial biochemical reactions. FA molecular structure is made up of three components: a pteridine portion linked by through p-aminobenzoic acid to L-glutamic acid (Figure 1). The acyl group coming from the pteroic acid is a pteroyl group [3]. 


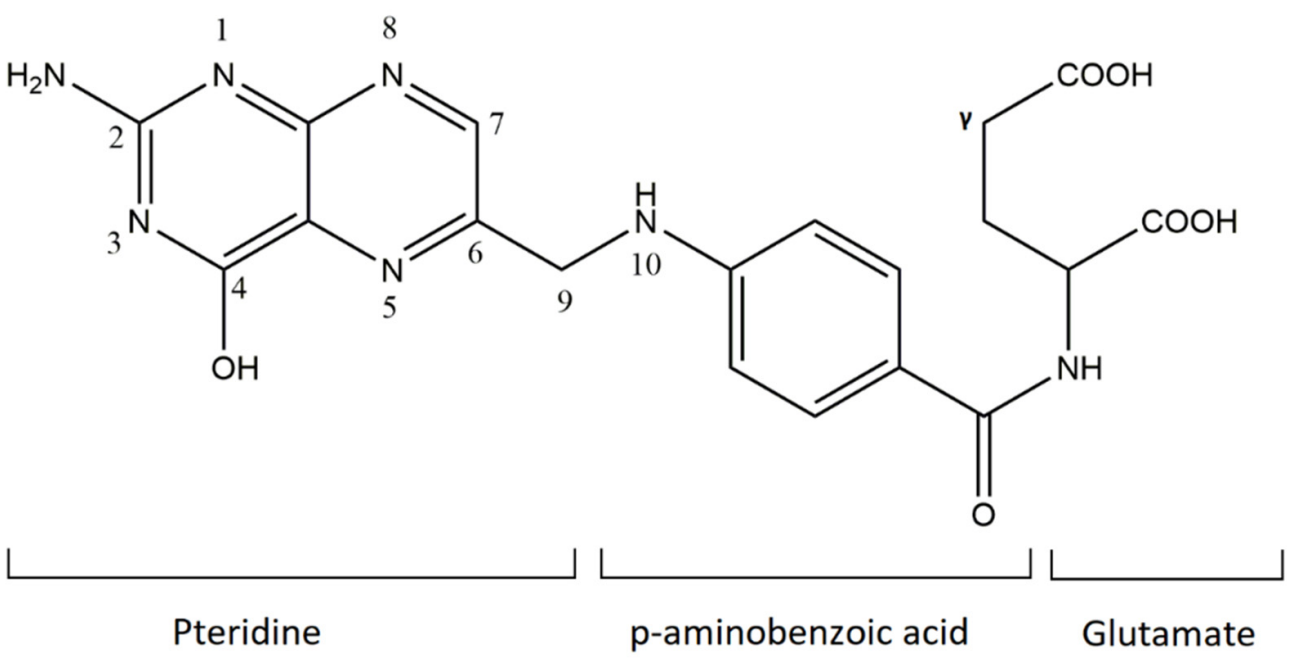

Figure 1. Schematic representation of folic acid (mono-glutamate derivate).

FA, though, has no biological activity itself but acts as fundamental precursor of a group of crucial coenzymes. Furthermore, FA is not produced by human body, and thus it must be obtained through diet (in the folate form), including liver, yolk, kidney beans, green leafy vegetables and fresh fruits [4]. Due the extreme importance of FA in cell proliferation, its assimilation is more and more frequently achieved by taking food supplements [5]. Indeed, all cells need folate in its reduced form in order to renew their cellular components. Tetrahydrofolate, for instance, acts as a cofactor in some essential metabolic pathways, such as DNA synthesis and biological methylation [6]. Different organisms exploit different strategies to obtain folate: plants and some microorganisms can produce folate from scratch with minimal variations of the same biosynthetic pathway [7-9]. Conversely, mammals, being auxotrophs, obtain folate through their diet or by exploiting intestinal bacteria capable of synthesizing it $[10,11]$. Despite all the different functions of the folate coenzyme, the main one is to transfer one-carbon groups in a variety of synthetic reactions. This capability varies depending upon the state of oxidation of the transferred group. Furthermore, FA can participate in a plethora of key reactions for fundamental cell functions: among the most important reported are the synthesis of purines, pyrimidines (and thus, indirectly, in the synthesis of DNA) and methionine, and the repair and methylation of DNA. Folate deficiency may result in degenerative conditions, such as neural tube defects in developing embryos and megaloblastic anaemia at any age [12]. Being water-soluble, folate cannot be stored in the human body and consequently is continuously lost. Therefore, its deficiency is one of the most commonly found vitamin deficits. The effective folate lack in the world is not well understood even though it appears a usual condition for many vulnerable classes. The use of so-called FA antagonists in certain disease (such as cancer [13], leukaemia [14], psoriasis [15], rheumatoid arthritis [16,17], polymyositis [18,19], dermatomyositis $[20,21]$ and so on) may seem to suggest that a folate surplus in the diet would be harmful. Moreover, there have recently been rising concerns that FA supplementation could actually increase the risk of cancer frequency [22], as animal and human studies have indicated that high folate status may promote the progression of preneoplastic and undiagnosed neoplastic lesions $[23,24]$. There is little evidence to support such a view, nor it is well understood if FA supplements hamper the therapeutic effectiveness of these medications. Due to FA's ability to itself act as dihydrofolate reductase inhibitor, it could quite possibly be not only reliable but even advantageous in the treatment of these disorders $[25,26]$. For this reason, FA supplements are widely used to prevent and handle folate deficiency in at-risk groups and also to prevent adverse events associated with antifolate medications [27]. A daily intake of FA, through the commercially available supplements, is recommended to fertile and pregnant women in order to limit possible neural disorders in developing fetuses [28]. Folate is highly recommended also in subjects 
with heart failure due to its ability to lower the blood-homocysteine level, which has been linked to increased risk of cardiovascular events [29,30]. Moreover, FA promotes the formation of vigorous and healthy red blood cells [31,32]. However, some countries decided to not adopt FA fortification, being afraid of the possible negative consequences $[33,34]$. All these different benefits and disadvantages have led the research world to develop and optimize analytical methods, which can dependably and accurately monitor the FA concentration in natural sources, fortified foods, and multivitamin dietary supplements. In Europe, the EFSA (European Food Safety Authority) balances the fortification of flour (wheat and maize), establishing a minimum and maximum of 140 and $220 \mu \mathrm{g}$ of FA per $100 \mathrm{~g}$. For women with a history of congenital malformation, the recommended daily dose is $5 \mathrm{mg}$ to reduce the risk of recurrence of the problem. A plethora of different analytical methods have been applied to determine FA in natural sources, using laboratory instrumentation as thermogravimetry [35], spectrophotometry [36,37], high performance liquid chromatography (HPLC) [38,39] with mass spectroscopy [40,41], colorimetry [42,43], fluorescence [44], electrophoresis [45,46] and so on (Table 1). Recently, an interesting overview about the future trends in the market for electrochemical biosensing has been proposed in [47], in which the current outline of the sensors and biosensors market is summarized. Some of the most recent advances are discussed, along with future prospects for biosensing development that could make an impact on the future global market. This short review reports on research papers of the past 5 years (2016-2020) dealing with the electrochemical determination of FA in food or biological fluid samples.

Table 1. Summary of analytical methods for the determination of FA in various samples.

\begin{tabular}{|c|c|c|c|c|c|c|}
\hline Analyte & Technique & $\mathbf{L R}$ * & LOD & Sensitivity & RSD $\%$ & Ref \\
\hline $\begin{array}{l}\text { FA in pharmaceutical } \\
\text { preparations }\end{array}$ & $\begin{array}{l}\text { Spectrophotometric determination by } \\
\text { coupling reaction }\end{array}$ & $0.1-8.0 \mu \mathrm{g} \mathrm{mL}^{-1}$ & $0.0469 \mu \mathrm{g} \mathrm{mL}^{-1}$ & $0.0066 \mu \mathrm{g} \mathrm{cm}^{-2}$ & 0.2805 & [36] \\
\hline FA in vegetables & HPLC-UV-Vis & $0.3-100 \mathrm{ng} \mathrm{mL}^{-1}$ & $0.1 \mathrm{ng} \mathrm{mL}^{-1}$ & / & 0.3 & [39] \\
\hline FA in beer & LC-MS/MS & / & $0.3 \mu \mathrm{g} \mathrm{L}^{-1}$ & $1.2 \mu \mathrm{g} \mathrm{L}^{-1}$ & / & [40] \\
\hline FA in egg yolks & $\begin{array}{l}\text { Modified EMR-lipid method } \\
\text { combined with HPLC-MS/MS }\end{array}$ & $0.1-100 \mathrm{ng} \mathrm{mL}^{-1}$ & $18.3 \mathrm{ng} \mathrm{mL}^{-1}$ & / & $\begin{array}{c}3.9(\mathrm{HC}) \\
8.1(\mathrm{MC}) \\
10(\mathrm{LC})\end{array}$ & [41] \\
\hline \multirow{2}{*}{$\begin{array}{l}\text { FA in commercial } \\
\text { preparations }\end{array}$} & Chemiluminometric procedure & $6.0-114 \mu \mathrm{g} \mathrm{mL}^{-1}$ & $2.0 \mu \mathrm{g} \mathrm{mL}^{-1}$ & \multirow{2}{*}{ / } & 1 & \multirow{2}{*}{ [44] } \\
\hline & Fluorimetric procedure & $0.02-1.1 \mu \mathrm{g} \mathrm{mL}^{-1}$ & $0.002 \mu \mathrm{g} \mathrm{mL}^{-1}$ & & 0.7 & \\
\hline FA in human urine & Capillary electrophoresis & $0.5-6.0 \mathrm{mg} \mathrm{L}^{-1}$ & $0.30 \mathrm{mg} \mathrm{L}^{-1}$ & / & $\begin{array}{l}0.4-0.7(\mathrm{MT}) \\
2.0-3.9(\mathrm{PA}) \\
1.2-1.7(\mathrm{PH})\end{array}$ & [45] \\
\hline $\begin{array}{l}\text { FA in pharmaceutical } \\
\text { tablets }\end{array}$ & $\begin{array}{l}\text { Capillary electrophoresis with } \\
\text { chemiluminescence determination }\end{array}$ & $5.0 \times 10^{-8}-10^{-5} \mathrm{M}$ & $2.0 \times 10^{-8} \mathrm{M}$ & / & $\begin{array}{l}1.1(\mathrm{MT}) \\
1.5(\mathrm{PA}) \\
4.9(\mathrm{PH})\end{array}$ & [46] \\
\hline $\begin{array}{l}\text { FA in pharmaceutical } \\
\text { preparations }\end{array}$ & $\begin{array}{l}\text { Flow-injection/chemiluminescence } \\
\text { determination }\end{array}$ & $2.5 \times 10^{-5}-3 \times 10^{-7} \mathrm{M}$ & $2.3 \times 10^{-8} \mathrm{M}$ & / & 3.5 & [48] \\
\hline
\end{tabular}

* LR (linear range), LOD (limit of detection), RSD (relative standard deviation), HC (high-concentration), MC (medium-concentration), LC (low-concentration), MT (migration time), PA (peak area) and PH (peak height).

\section{Electrochemical Determination}

In recent decades, the growing interest in FA, due to its physiological importance, has involved the development of a plethora of methods for its determination [49]. Thus, a sensitive, specific and easy-to-use way to quantify FA is crucial. In this section, a collection of the most relevant and original electrochemical sensors of the past 5 years for FA determination is reported. In particular, two different subsections are mentioned: traditional and screen-printed based sensors.

\subsection{Traditional Sensors}

In 2018, Mohammadi et al. [50] aimed to fabricate an FA-sensitive platform based on manganese ferrite nanoparticles modified by means of trimethoxy silane (3-amynopropyl). In particular, in this study, core shell magnetic nanoparticles (CMNP) were involved in 
order to produce 2FTNE ((2-(4-Ferrocenyl-[1,2,3]triazol-1-yl)-1-(naphthalen-2-yl) ethanone), successively used in the modification of CMPE paste electrodes (2FTNE-modified CMNP paste electrodes), whereby this platform has been carefully characterized. The main goal of this research study was the concurrent measurements of epinephrine (EP), uric acid (UA) and FA. For this purpose, the concentrations of these analytes were simultaneously changed over time. The analysis was conducted using 2FTNE-modified CMNP paste electrodes (2FTNEMCPPE) and square wave voltammetry (SWV) as electrochemical technique, as reported in Figure 2. It is possible to observe that three well-distinguished anodic peaks at defined potentials of 430, 730 and $930 \mathrm{mV}$, corresponding to the oxidation peaks of $\mathrm{EP}$, UA and FA, respectively, were obtained, which confirmed that the concurrent measurements of these analytes was possible (Figure 2). With the use of bare CPE, an overlapping voltammogram for the analytes was obtained. The sensitivity of the 2FTNEMCNPPE toward EP was

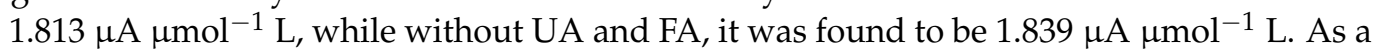
consequence, it is possible to have the independent or the concurrent measurements and quantification of EP, UA and FA. Finally, 2FTNEMCNPPE was applied to measure EP, UA and FA in an EP ampoule, an FA tablet and urine samples. All the different outcomes are summarized in Table 2. In addition, the recovery of EP, UA and FA of the samples spiked with known amounts of EP, UA and FA was assessed.

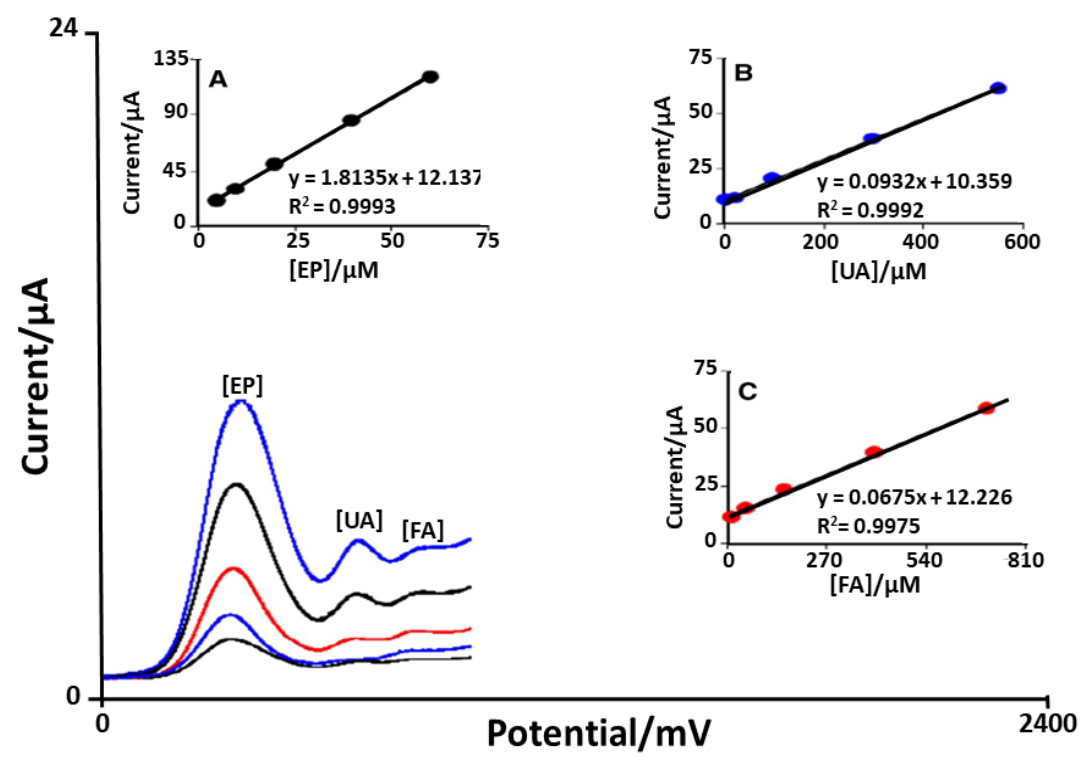

Figure 2. SWVs of 2FTNEMCNPPE in $0.1 \mathrm{M}$ PBS ( $\mathrm{pH} 7.0)$ with various concentrations $\left(\mu \mathrm{mol} \mathrm{L}{ }^{-1}\right)$ of EP, UA FA in a mixed solution: (1) $5.0+5.0+10.0$, (2) $50.0+25.0+10.0$, (3) $150.0+100.0+20.0$, (4) $400.0+300.0+40.0$, (5) $700.0+550.0+60.0$. (A-C): plots of peak currents as a function of EP, UA and FA concentration, respectively [50].

Back in 2016, Lavanya et al. [51] developed a selective electrochemical sensor based on $\mathrm{Mn}$ doped $\mathrm{SnO}_{2}$ nanoparticles (NPs) modified glassy carbon electrode ( $\left.\mathrm{Mn}-\mathrm{SnO}_{2} / \mathrm{GCE}\right)$. In particular, this platform was employed for the simultaneous determination of ascorbic acid (AA), uric acid (UA) and FA. These nanoparticles were synthesized by microwave irradiation and fully characterized using different spectroscopical and morphological techniques: $\mathrm{X}$-ray diffraction (XRD), transmission electron microscopy (TEM), X-ray photoelectron spectroscopy (XPS), vibrating sample magnetometer (VSM), EIS, CV and SWV, respectively. AA is an important interfering analyte, which coexists with FA and UA in real body fluids. For this reason, the concentrations of UA and FA were determined in presence of a very high concentration of AA. The SWVs, reported in Figure 3, were obtained from the mixture of UA and FA in the presence of $200 \mu \mathrm{M}$ AA. 
Table 2. The use of 2FTNEMCNPPE in simultaneous quantification of EP, UA and FA in an EP ampule, an FA tablet and urine samples $(n=5)$. The amounts of EP and FA in ampoules and tablets were found to be equal to $0.98 \mathrm{mg} \mathrm{mL}^{-1}$ and $1.01 \mathrm{mg} /$ tablet, respectively. These outcomes show no significant difference between the results of the 2FTNEMCNPPE and the nominal value on the ampoule label and tablet label (1.00 $\mathrm{mg} \mathrm{mL}^{-1}$ and $1.00 \mathrm{mg} / \mathrm{tablet}$, respectively) [50].

\begin{tabular}{cccccccccccccc}
\hline Sample & \multicolumn{3}{c}{ Spiked $(\mu \mathbf{M})$} & \multicolumn{3}{c}{ Found $(\mu \mathbf{M})$} & \multicolumn{3}{c}{ Recovery (\%) } & \multicolumn{3}{c}{ R.S.D. (\%) } \\
\hline & EP & UA & FA & EP & UA & EP & EP & UA & FA & EP & UA & FA \\
\hline EP ampoule & 0 & 0 & 0 & 9.0 & - & - & - & - & - & 2.7 & - \\
& 2.5 & 15.0 & 17.5 & 11.4 & 15.5 & 17.1 & 99.1 & 103.3 & 97.7 & 3.2 & 1.9 & 2.8 \\
& 5.0 & 25.0 & 27.5 & 14.3 & 24.8 & 27.9 & 102.1 & 99.2 & 101.4 & 3.1 & 2.3 & 2.7 \\
& 7.5 & 35.0 & 37.5 & 17.1 & 35.1 & 37.3 & 103.6 & 100.3 & 99.5 & 1.9 & 3.3 & 2.4 \\
& 10.0 & 45.0 & 47.5 & 18.5 & 45.6 & 48.8 & 97.3 & 101.3 & 102.7 & 2.2 & 1.8 & 3.1 \\
& 0 & 0 & 0 & - & - & 17.0 & - & - & - & - & 3.4 & - \\
& 5.0 & 17.5 & 2.5 & 5.1 & 17.1 & 19.7 & 102.7 & 97.7 & 101.0 & 2.3 & 1.9 & 3.2 \\
& 10.0 & 2.5 & 5.0 & 9.8 & 22.9 & 21.9 & 98.0 & 101.8 & 99.5 & 3.1 & 2.3 & 1.9 \\
& 15.0 & 27.5 & 7.5 & 15.1 & 27.1 & 24.3 & 100.7 & 98.5 & 99.2 & 1.7 & 2.8 & 2.7 \\
& 20.0 & 32.5 & 10.0 & 19.8 & 33.5 & 27.5 & 99.0 & 103.1 & 101.8 & 2.8 & 3.1 & 1.8 \\
& 0 & 0 & 0 & - & 10 & - & - & - & - & - & - & - \\
& 7.5 & 10.0 & 30.0 & 7.4 & 20.2 & 30.9 & 98.7 & 101.0 & 103.0 & 2.9 & 3.2 & 1.6 \\
& 12.5 & 20.0 & 40.0 & 12.7 & 29.5 & 39.1 & 101.6 & 98.3 & 97.7 & 3.4 & 2.7 & 2.6 \\
& 17.5 & 30.0 & 50.0 & 18.1 & 41.2 & 49.5 & 103.4 & 103.0 & 99.0 & 1.6 & 2.6 & 3.1 \\
& 22.5 & 40.0 & 60.0 & 22.4 & 49.8 & 61.5 & 99.5 & 99.6 & 102.4 & 2.2 & 1.8 & 2.9 \\
\hline
\end{tabular}

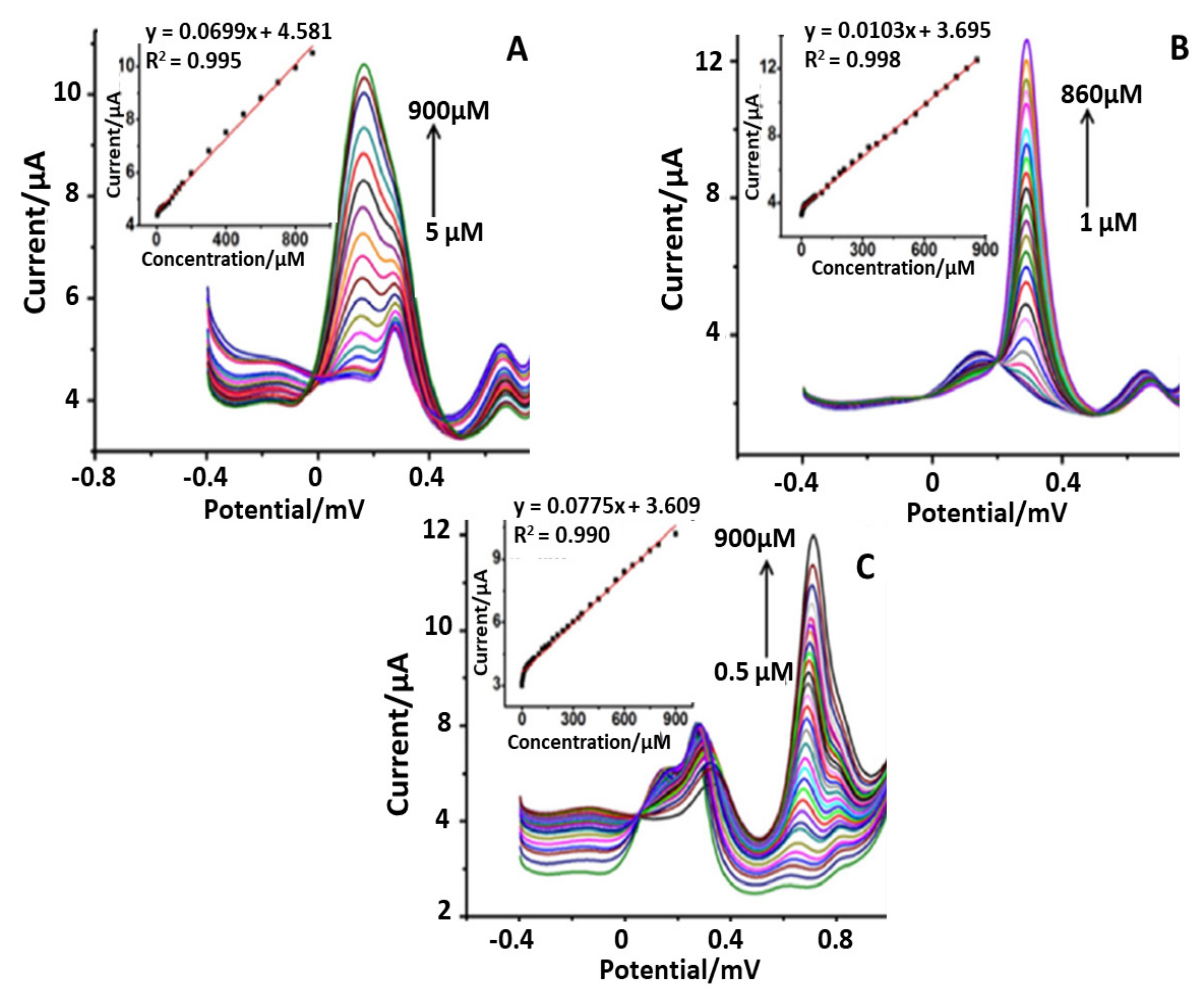

Figure 3. SWVs obtained for various concentrations of UA (5 to $500 \mu \mathrm{M})(\mathbf{A})$ and FA (1 to $800 \mu \mathrm{M})$ (B) at $\mathrm{Mn} \mathrm{SnO}_{2} / \mathrm{GCE}$ in the presence of $200 \mu \mathrm{M}$ AA in $0.1 \mathrm{M}$ PBS (pH 6.0) and inreal samples (C). (insert of $\mathbf{A}-\mathbf{C}$ ): plots of the oxidation peak currents as a function of various concentrations of UA and FA, respectively [51].

It can be easily noticed (Figure 3A) that simultaneously increasing the FA and UA concentrations a corresponding linear increase in the anodic peak currents have been obtained. Thus, a linear relationship between analytes concentration and their anodic peak currents is established. Furthermore, using different concentrations of UA and FA 
(in the range 5.0 to $500 \mu \mathrm{M}$ for UA and 1.0 to $500 \mu \mathrm{M}$ for FA), detection limits of 0.025 and $0.038 \mu \mathrm{M}$, respectively, have been obtained. To verify the applicability of this platform (Mn$\mathrm{SnO}_{2} /$ GCE sensor) to real samples, $\mathrm{AA}$ and FA have been determined in pharmaceutical products. A recovery value corresponding to $99.4 \%$ (labeled content of FA mg/tablet 5 , observed content of FA mg/tablet 4.88) was found using $3 \mathrm{wt} \% \mathrm{Mn}-\mathrm{SnO}_{2} / \mathrm{GCE}$. Thus, the method studied could be reliably applied for the determination of FA and AA in commercial samples.

Another important work, published in 2020 by Sadeghi et al. [52], proposed an electrochemical amplified FA sensor based on paste electrode (PE) modified with CuO-CNTs and 1-butyl-2,3-dimethylimidazolium hexafluorophosphate (BDHFP). Specifically, this device is based on the FA oxidation current registered by means of DP voltammograms, which increased 2.8 times using PE/M/CuO-CNTs-BDHFP with respect to PE. The modification produced an increase in the active surface area of $P E$ (from $0.11 \mathrm{~cm}^{2}$ to $0.18 \mathrm{~cm}^{2}$ after modification with CuO-CNTs and BDHFP). DP voltammograms of different concentrations of FA were recorded on the surface of PE/M/CuO-CNTs/BDHFP with a linear dynamic range between $3.0 \mathrm{nM}$ and $250 \mu \mathrm{M}$ with a detection limit of $0.8 \mathrm{nM}$ using PE/M/CuOCNTs/BDHFP as an electrochemical sensor (Figure 4).

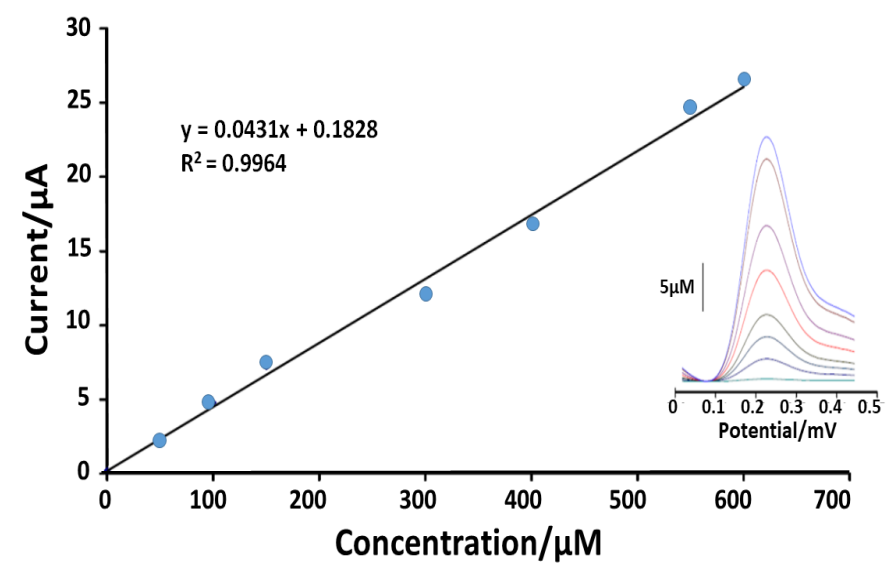

Figure 4. Current-concentration curve for the oxidation of FA in the range of $3.0 \mathrm{nM}-250 \mu \mathrm{M}$. Inset: relative DP voltammograms of FA at surface of PE/CuO-CNTs/BDHFP [52].

The ability of PE/CuO-CNTs/BDHFP was also tested in real samples. To this purpose, it is employed in the determination of FA in orange and apple juices by applying the standard addition method (data repeated in Table 3). The results, summarized in Table 3 , confirmed the powerful performances of this sensors for real sample analysis.

Table 3. Real sample analysis of FA using PE/CuO-CNTs/BDHFP ( $n=4)$ [52].

\begin{tabular}{ccccc}
\hline Sample & FA Added $(\mu \mathbf{M})$ & FA Expected $(\mu \mathbf{M})$ & FA Found $(\mu \mathbf{M})$ & Recovery $\%$ \\
\hline \multirow{2}{*}{ Orange Juice } & $/$ & $/$ & $9.89 \pm 0.54$ & $/$ \\
\cline { 2 - 5 } & 10.00 & 19.89 & $20.21 \pm 0.87$ & 101.6 \\
\hline \multirow{2}{*}{ Apple Juice } & $/$ & $/$ & $8.51 \pm 0.34$ & $/$ \\
\cline { 2 - 5 } & 10.00 & 18.51 & $18.38 \pm 0.65$ & 99.29 \\
\hline
\end{tabular}

Mollaei et al. [53] in 2019 reported an electrochemical sensor for FA detection based on the adsorption of a cationic surfactant (n-dodecylpyridinium chloride, DPC), at the surface of carbon paste electrode (CPE). The electrochemical performances in FA detection were compared with cetyltrimethylammonium bromide (CTAB). This quantitative analysis is performed using different voltammetric techniques: the differential pulse voltammetry (DPV), cyclic voltammetry (CV) and chronocoulometry (CC). Moreover, the determination of FA in urine and pharmaceuticals were performed in order to demonstrate the capability 
of the improved method and its reproducibility in real sample matrix (Figure 5). To overcome the matrix effect drawback, in both cases, the conventional standard addition method was utilized. The results are summarized in Table 4, indicating acceptable recoveries (ranging between 94.1 and 103.5) and working range.
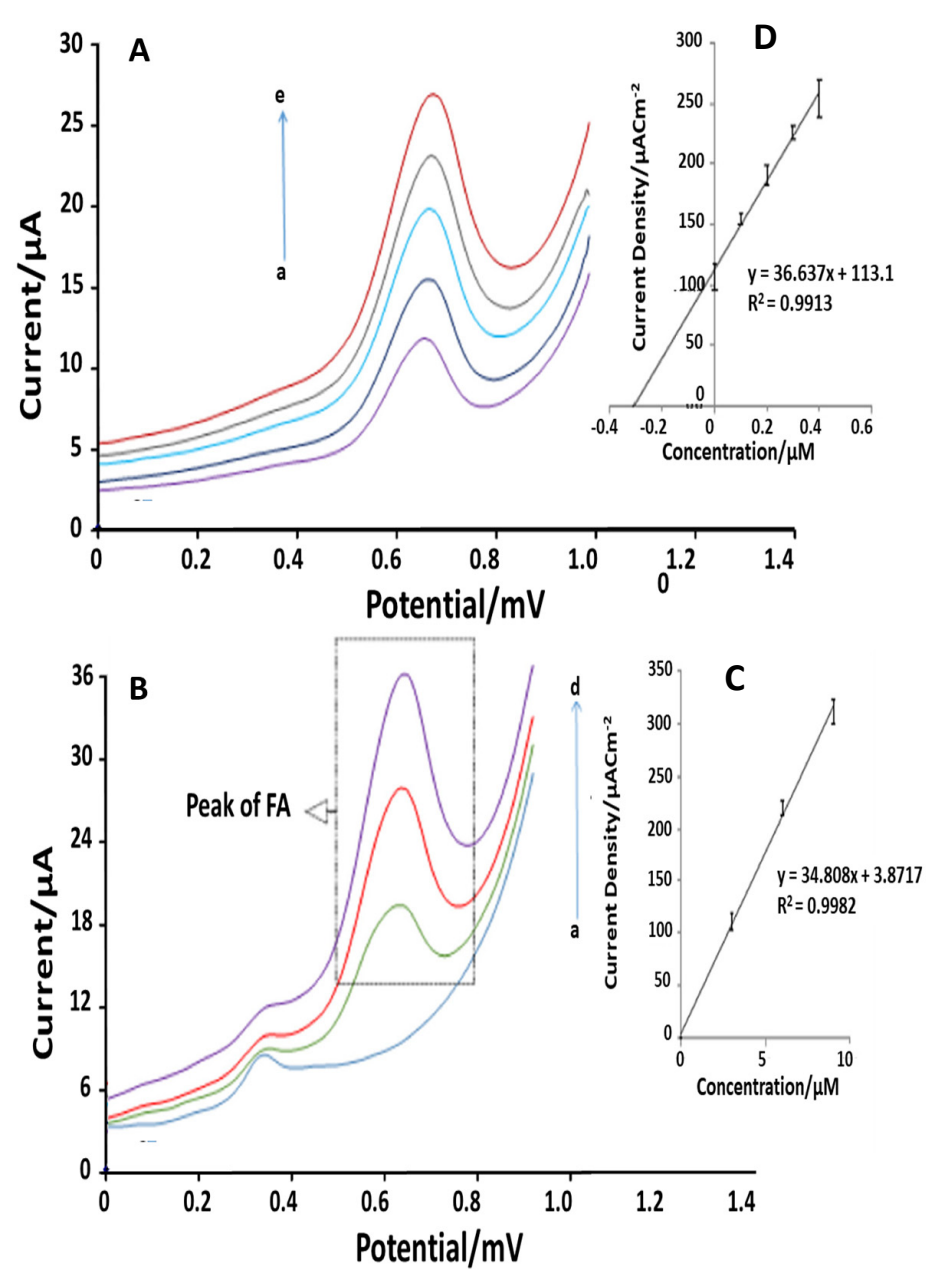

Figure 5. (A): Differential pulse voltammograms of CPE in $0.1 \mathrm{M} \mathrm{PB}(\mathrm{pH}=8.0)$ and drug tablet (3.0 $\mu \mathrm{M} \mathrm{FA}$ ) containing different concentrations of pure FA: a-e corresponds to $0.0-4.0 \mu \mathrm{M}$ of pure FA. (B): Differential pulse voltammograms of CPE in $0.1 \mathrm{M} \mathrm{PB}(\mathrm{pH}=8.0)$ and $0.2 \mathrm{~mL}$ of a urine sample containing a different concentration of FA: the letters a-d correspond to $0.0-9.0 \mu \mathrm{M}$ of FA. (C,D): Standard addition curve of the peak current density J $\left(\mu \mathrm{M} \mathrm{cm}^{-2}\right)$ (extrapolated from respectively voltammograms A and B) vs. the concentration of FA [53].

Table 4. Determination of FA in drug tablet and urine samples by applying differential pulse voltammetry at the surface of CPE [53].

\begin{tabular}{ccccc}
\hline Sample & Initial Found $(\mu \mathbf{M})$ & Added $(\mu \mathbf{M})$ & Found $(\mu \mathbf{M})$ & Recovery $(\%)$ \\
\hline \multirow{4}{*}{ TABLET } & 3.0 & 0.0 & 2.82 & 94 \\
& 3.0 & 1.0 & 4.14 & 104 \\
& 3.0 & 2.0 & 5.11 & 102 \\
& 3.0 & 3.0 & 6.07 & 101 \\
\multirow{3}{*}{ URINE } & 3.0 & 4.0 & 6.86 & - \\
& 0.0 & 0.0 & 0.00 & 102 \\
& 0.0 & 3.0 & 3.07 & 103 \\
\hline
\end{tabular}


Looking at Figure 5, it can be noticed that CPE in the presence of DPC has good operating properties such as selectivity, sensitivity, stability, repeatability, low detection limit $(2.9 \mathrm{nM})$ and wide linear concentration range (0.01-10.69 mM). Finally, TahernejadJavazmi et al. [54] in 2019, using previous experience with electrochemical sensor employing $\mathrm{CuO}$ nanoparticle decorated on single wall carbon nanotubes $(\mathrm{CuO} / \mathrm{SWCNTs})$ nanocomposite and 1-butyl-3-methylimidazolium hexafluorophosphate [55], developed an electroanalytical sensor based on reduced graphene oxide (GO) modified carbon paste electrode (CPE). In particular, the GO modified platform were functionalized with $\mathrm{FeNi}_{3}$ $\left(\mathrm{FeNi}_{3}\right) / \mathrm{rGO}$-ionic liquid n-hexyl-3-methylimidazolium hexafluoro phosphate $\left(\mathrm{HMPF}_{6}\right)$. This platform was then employed for the simultaneous determination of FA and TBHQ (the antioxidant additive tertbutylhydroquinone), respectively. The modification process of $\mathrm{CPE}$ with $\mathrm{FeNi}_{3} / \mathrm{rGO}$ and $\mathrm{HMPF}_{6}$ was followed by EIS measurements (Figure $6 \mathrm{~A}$ ) and using $1.0 \mathrm{mM}\left[\mathrm{Fe}(\mathrm{CN})_{6}\right]^{3 / 4-}$ as an electrochemical probe. Using this technique and going from bare electrode to FeNi3-modifed platform $\left(\mathrm{FeNi}_{3} \mathrm{rGO} / \mathrm{HMPF}_{6} / \mathrm{CPE}\right)$, an important decrease in the charge transfer resistance (Rct) value (from $6480 \Omega$ to $870 \Omega$ ) was observed. This confirmed that the $\mathrm{FeNi}_{3} / \mathrm{rGO}$ and $\mathrm{HMPF}_{6}$ based modification improved conductivity and the electron transfer process at $\mathrm{CPE}^{\prime}$ s interface. The $\mathrm{FeNi}_{3} / \mathrm{rGO} / \mathrm{HMPF} / \mathrm{CPE}$ performances have been compared to previous published methods [56,57]. The results, displayed in Table 5, show the applicability of this modified CPE for real sample analysis.
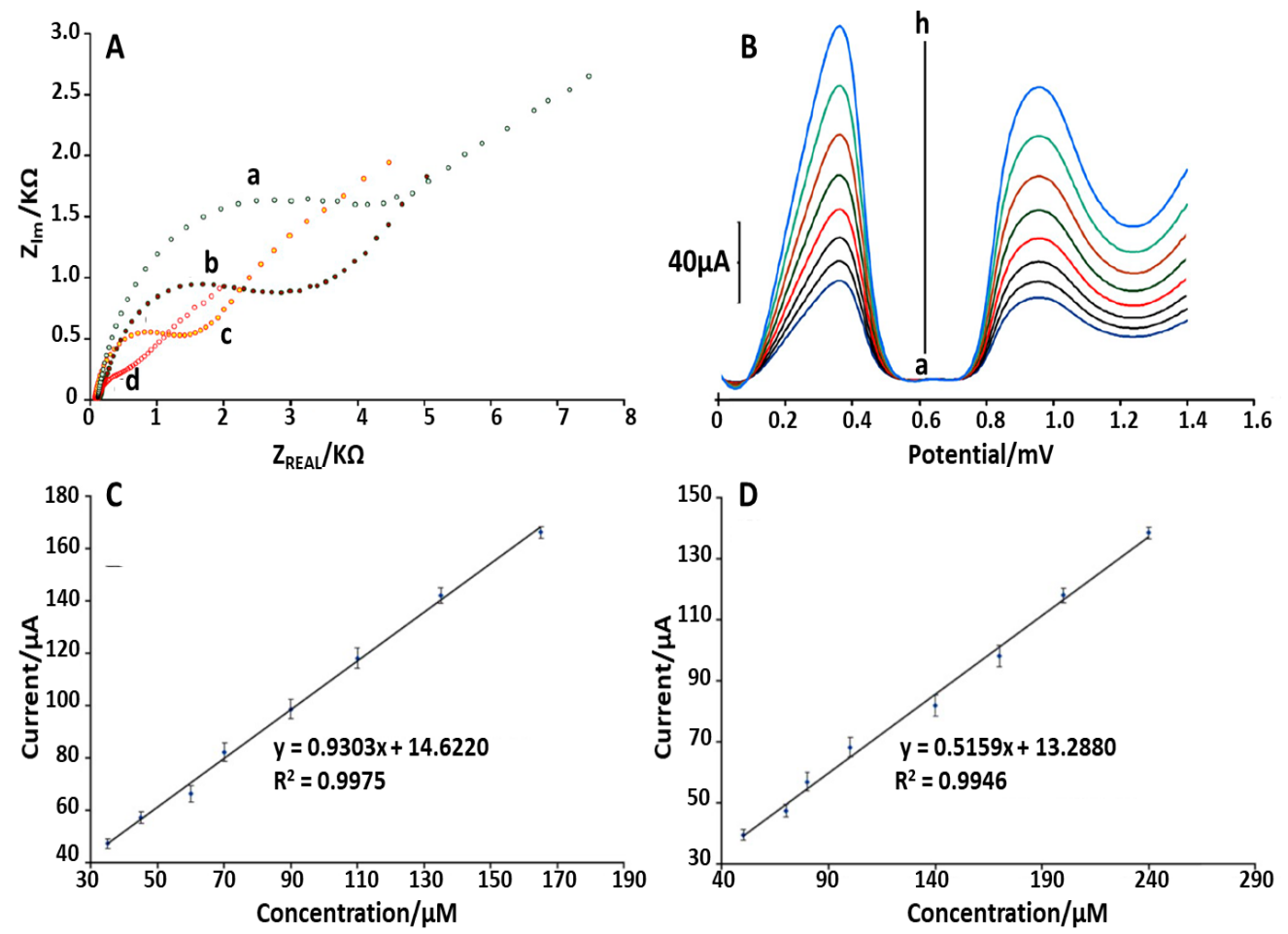

Figure 6. (A): Nyquist diagrams of (a) $\mathrm{CPE}$, (b) $\mathrm{FeNi}_{3} / \mathrm{rGO} / \mathrm{CPE}$, (c) $\mathrm{HMPF}_{6} / \mathrm{CPE}$ and (d) $\mathrm{FeNi}_{3} / \mathrm{rGO} /$ $\mathrm{HMPF}_{6} / \mathrm{CPE}$ in $1.0 \mathrm{mM}\left[\mathrm{Fe}(\mathrm{CN})_{6}\right]^{3-, 4-}$. (B): SW voltammograms of solution containing TBHQ and $\mathrm{FA}$ at the $\mathrm{FeNi}_{3} / \mathrm{rGO} / \mathrm{HMPF}_{6} / \mathrm{CPE}$; (a) $35.0+50.0$; (b) $45.0+70.0$; (c) $60.0+80.0$; (d) $70.0+100.0$; (e) $90.0+140.0$; (f) $110.0+170.0$; (g) $135.0+200.0$ and (h) $165.0+240.0 \mu \mathrm{M}$. (C): The Ipa vs. TBHQ concentration obtained from SW voltammograms. (D): The Ipa vs. folic acid concentration obtained from SW voltammograms [54]. 
Table 5. Determination of TBHQ and FA in real samples $(n=4)$ [54]. The different results are compared to those from previously published methods for TBHQ [57] and FA [56], respectively.

\begin{tabular}{cccccc}
\hline Sample & TBHQ Added & FA Added & $\begin{array}{c}\text { Found TBHQ } \\
\text { Proposed Method }\end{array}$ & $\begin{array}{c}\text { Found TBHQ } \\
\text { Published Method }\end{array}$ & $\begin{array}{c}\text { Found FA } \\
\text { Proposed Method }\end{array}$ \\
\hline Published Method
\end{tabular}

\subsection{Screen Printed Electrodes (SPEs)-Based Sensors}

Screen printed electrodes (SPEs)-based sensors are an improvement of traditional sensors for performing rapid and accurate in situ analyses and for the development of portable devices. In the past 5 years, few biosensors based on SPEs were developed for the detection of FA in pharmaceutical and biological products, as summarized in Table 6.

Table 6. Summary of biosensors based on SEPs for the determination of FA in various samples.

\begin{tabular}{|c|c|c|c|c|c|}
\hline Analyte & Technique & LOD & Working Range & Sample & Ref. \\
\hline Vitamin B9 in real specimens. & $\begin{array}{l}\text { SPE modified with } \mathrm{La}+3 / \mathrm{Co} 3 \mathrm{O} 4 \\
\text { nano-cubes. }\end{array}$ & $0.3 \mu \mathrm{M}$ & $1-600 \mu \mathrm{M}$ & $\begin{array}{l}\text { Human urine } \\
\text { samples, tablet. }\end{array}$ & {$[58]$} \\
\hline $\begin{array}{l}\text { N-acetylcysteine in the presence } \\
\text { of paracetamol and folic acid }\end{array}$ & $\begin{array}{c}\text { CPE modified with Pt-Co nanoparticles and } \\
\text { 2-(3,4 dihydroxy phenethyl) } \\
\text { isoindoline-1,3-dione }\end{array}$ & $0.04 \mu \mathrm{M}$ & $0.08-650 \mu \mathrm{M}$ & $\begin{array}{l}\text { Human urine } \\
\text { samples, tablet. }\end{array}$ & {$[59]$} \\
\hline $\begin{array}{l}\text { Simultaneous determination of } \\
\text { sulfisoxazole and folic acid. }\end{array}$ & $\begin{array}{l}\mathrm{CuO} \text { Nanoparticles decorated on SWCNT } \\
\text { nanocomposite modified CPE. }\end{array}$ & $0.8 \mu \mathrm{M}$ & $0.07-500 \mu \mathrm{M}$ & $\begin{array}{l}\text { Human urine and } \\
\text { tablet. }\end{array}$ & {$[59]$} \\
\hline Folic acid in real specimens. & $\begin{array}{l}\text { SPE modified with Graphene Oxide } \\
\text { Nanoribbons }\end{array}$ & $0.02 \mu \mathrm{M}$ & $0.1-1600 \mu \mathrm{M}$ & $\begin{array}{l}\text { Human urine } \\
\text { samples, tablet }\end{array}$ & {$[60]$} \\
\hline Folic acid in real specimens. & $\begin{array}{l}\text { Mn-zeolite/Graphite modified } \\
\text { Screen-printed Carbon Electrode }\end{array}$ & $0.003 \mu \mathrm{M}$ & $0.004-1 \mu \mathrm{M}$ & $\begin{array}{l}\text { Pharmaceutical } \\
\text { samples }\end{array}$ & {$[61]$} \\
\hline Folic acid in real specimens. & SPE modified using GNS-MoS2-AuNPs & $38.5 \mathrm{nM}$ & $50 \mathrm{nM}-1150 \mu \mathrm{M}$ & Human urine & {$[62]$} \\
\hline $\begin{array}{l}\text { Simultaneous determination of } \\
\text { folic acid and epinephrine }\end{array}$ & Graphite SPE modified with $\mathrm{Fe} 3 \mathrm{O} 4 @ \mathrm{SiO}_{2}$ & $1 \mu \mathrm{M}$ & $5-1000 \mu \mathrm{M}$ & $\begin{array}{l}\text { Human blood } \\
\text { serum and urine }\end{array}$ & {$[63]$} \\
\hline Folic acid in real specimens. & SPE modified with $\mathrm{NiFe}_{2} \mathrm{O}_{4}$ nanoparticles & $0.034 \mu \mathrm{M}$ & $0.1-500 \mu \mathrm{M}$ & Human urine & [64] \\
\hline
\end{tabular}

The great results have been achieved in the application of SPEs for the detection of FA and the main results are described below in detail.

In 2016, Mani et al. [62] developed a facile method to determine FA in real samples. In this work, the preparation of a ternary nanocomposite made of graphene nanosheets (GNS), molybdenum disulfide ( $\mathrm{MoS}_{2}$ ) and gold nanoparticles (AuNPs) were detailed and its electrochemical sensing suitability studied. This ternary nanocomposite, GNS-MoS ${ }_{2}-$ AuNPs, characterized by particle sizes of about $10-50 \mathrm{~nm}$, is deposited onto the surface of screen-printed electrodes (SPE) and applied for the quantification of FA. Due to the good synergic effect between GNS, $\mathrm{MoS}_{2}$ and AuNPs, the composite shows excellent electrocatalytic ability. Impedance and electrochemical attributes of the nanocomposite were carefully studied: charge transfer resistance $\left(R_{\mathrm{ct}}\right)$ compared (Figure 7) for unmodified SPE, $\mathrm{MoS}_{2} / \mathrm{SPCE}, \mathrm{GNS}-\mathrm{MoS}_{2} / \mathrm{SPCE}$ and GNS-MoS $-\mathrm{AuNPs} / \mathrm{SPE}$. The $\mathrm{R}_{\mathrm{ct}}$ values are reported in the following order: unmodified SPE $>\mathrm{MoS}_{2} / \mathrm{SPE}>\mathrm{GNS}-\mathrm{MoS}_{2} / \mathrm{SPE}>\mathrm{GNS}-$ $\mathrm{MoS}_{2}-\mathrm{AuNPs} / \mathrm{SPE}$, respectively. In particular, $\mathrm{R}_{\mathrm{ct}}$ obtained at GNS-MoS 2 -AuNPs/SPE is the lowest compared with control electrodes, indicating lowest resistance at this electrode interface. Thus, the electrochemical impedance spectroscopy (EIS) results revealed that the GNS- $\mathrm{MoS}_{2}-\mathrm{AuNPs}$ composite interface presents a better electrical conductivity 
than the other platforms. Furthermore, this EIS study was followed by a potentiometric investigation in amperometry. Using this technique, the determination of FA in human urine sample occurs in a wide linear range of $50 \mathrm{nM}-1150 \mu \mathrm{M}$ and displays low detection limit of $38.5 \mathrm{nM}$. To apply these platforms in real samples, a recovery study was conducted, obtaining satisfactory results (values range from 97.16 to $98.55 \%$ ). The sensor performance of the GNS- $\mathrm{MoS}_{2}-\mathrm{AuNPs}$ is either superior or comparable to the previously reported electrodes [65-67].

A

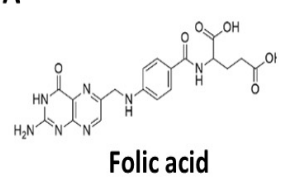

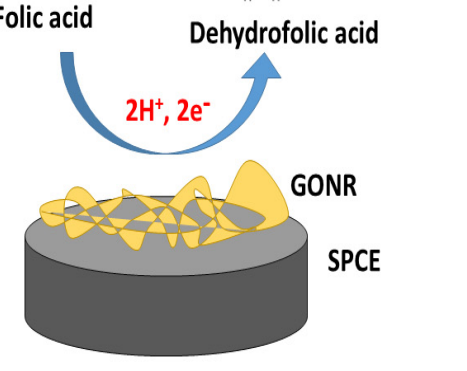

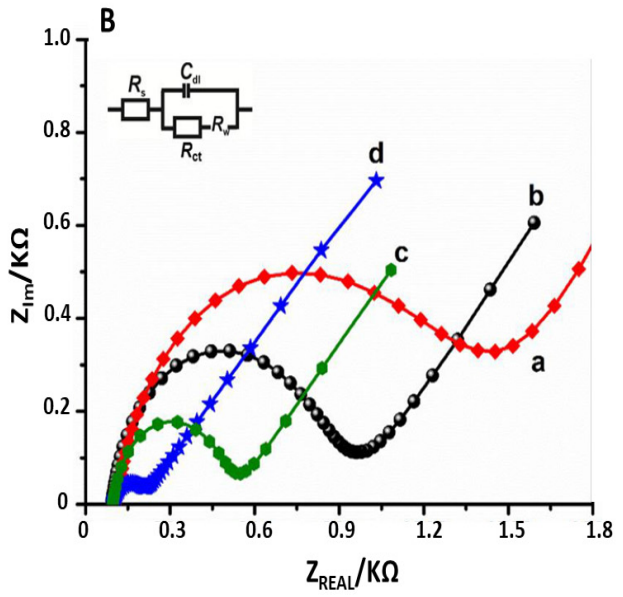

Figure 7. (A): Scheme of the electrochemical oxidation of FA on GONR/SPE. (B): EIS curves of unmodified SPE (a) $\mathrm{MOS}_{2}$-SPE (b), GNS-MoS 2 /SPE (c), $\mathrm{MoS}_{2}$-AuNPs/SPE, (d) in $0.1 \mathrm{M} \mathrm{KCl}$ containing $5 \mathrm{mM} \mathrm{Fe}(\mathrm{CN})_{6}{ }^{3-/ 4-}$. Frequency: $0.1 \mathrm{~Hz}$ to $100 \mathrm{kHz}$ [63].

Safaei and co-workers [63] in 2019 proposed a device for the simultaneous determination of FA and epinephrine (EP). This sensitive and convenient electrochemical sensor is based on $\mathrm{Fe}_{3} \mathrm{O}_{4} @ \mathrm{SiO}_{2} / \mathrm{GR}$ nanocomposite modified graphite SPE using cyclic voltammetry as detection tools. In particular, cyclic voltammograms ( $\mathrm{CVs}$ ) were recorded in the presence of analytes after having cycled the potential 20 times at a scan rate of $50 \mathrm{mV} \mathrm{s}^{-1}$. The peak potentials were unchanged and the currents decreased by less than $2.3 \%$. Therefore, at the surface of $\mathrm{Fe}_{3} \mathrm{O}_{4} @ \mathrm{SiO}_{2} / \mathrm{GR} / \mathrm{SPE}$, not only the sensitivity increases, but the fouling effect of the analyte and its oxidation product also decreases. To ascertain the analytical applicability of the proposed method, real samples matrices were evaluated. In particular, the simultaneous determination of epinephrine and FA, using the standard addition method and DPV as analytical technique, in human blood serum, urine, epinephrine injection and folic acid tablets samples, were analyzed in depth. In Table 7, the relative results are reported.

Satisfactory recoveries were found for epinephrine and FA, as reported in the above table. Reproducibility is reported as mean relative standard deviations (RSD\%). The sensor exhibited notable electrochemical activity towards the oxidation of epinephrine and FA, and solved the overlapping anodic peak outcomes of EP and FA into two well-defined peaks.

Safaei et al. [64], in 2019, successfully synthesized and used $\mathrm{NiFe}_{2} \mathrm{O}_{4}$ (NFO) nanoparticles in order to develop a modified novel voltammetric sensor for determination of FA in urine samples. The morphological characterization of NFO nanoparticles was examined by means of scanning-electron microscopy (SEM), and it was observed that all the particles are nearly spherical, not agglomerated and less than $10 \mathrm{~nm}$. In Figure 8C, cyclic voltammograms (CVs) are depicted, obtained using NFO-modified SPE. Analyzing equal concentration of substrate, NFO/SPE shows much higher anodic peak currents for the oxidation of folic acid compared to the unmodified SPE. This indicates that the modification of bare SPE with $\mathrm{NiFe}_{2} \mathrm{O}_{4}$ nanoparticles has significantly improved the performance in terms of electron transfer process between the electrode and the folic acid. In Figure 8C, the effect of potential scan rates on the oxidation currents of FA is described. 
Table 7. Determination of epinephrine and FA in human blood serum, urine, epinephrine injection and folic acid tablet samples. All the concentrations are in $\mu \mathrm{M}(\mathrm{n}=5)$ [63].

\begin{tabular}{|c|c|c|c|c|c|c|c|c|}
\hline \multirow{2}{*}{ Sample } & \multicolumn{2}{|c|}{ Spiked } & \multicolumn{2}{|c|}{ Found } & \multicolumn{2}{|c|}{ Recovery, \% } & \multicolumn{2}{|c|}{ Rsd \% } \\
\hline & Epinephrine & FA & Epinephrine & FA & Epinephrine & FA & Epinephrine & FA \\
\hline \multirow{3}{*}{ Human blood serum } & 0 & 0 & - & - & - & - & - & - \\
\hline & 10.0 & 5.0 & 10.3 & 4.9 & 103.0 & 98.0 & 3.2 & 2.4 \\
\hline & 20.0 & 60.0 & 19.8 & 61.6 & 99.0 & 102.7 & 17 & 2.7 \\
\hline \multirow{3}{*}{ Urine } & 0 & 0 & - & - & - & - & - & - \\
\hline & 12.5 & 45.0 & 12.3 & 45.3 & 98.4 & 100.7 & 2.4 & 3.1 \\
\hline & 22.5 & 55.0 & 23.1 & 53.7 & 102.6 & 97.6 & 1.8 & 2.8 \\
\hline \multirow{3}{*}{ Epinephrine Injection } & 0 & 0 & 10.5 & - & - & - & 3.2 & - \\
\hline & 2.5 & 30.0 & 12.7 & 30.3 & 97.7 & 101.0 & 1.9 & 2.6 \\
\hline & 5.0 & 39.7 & 15.9 & 40.3 & 102.6 & 99.2 & 2.4 & 3.3 \\
\hline \multirow{3}{*}{ Folic Acid Tablet } & 0 & 0 & - & 15.0 & - & - & - & 2.7 \\
\hline & 5.0 & 25.0 & 4.9 & 0.9 & 98.0 & 102.2 & 2.4 & 1.6 \\
\hline & 10.0 & 35.0 & 10.1 & 49.2 & 101.0 & 98.4 & 2.7 & 3.0 \\
\hline
\end{tabular}

A

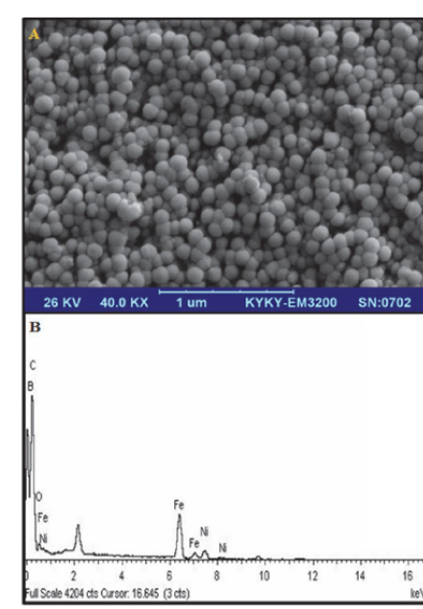

Screen Printed Electrodes

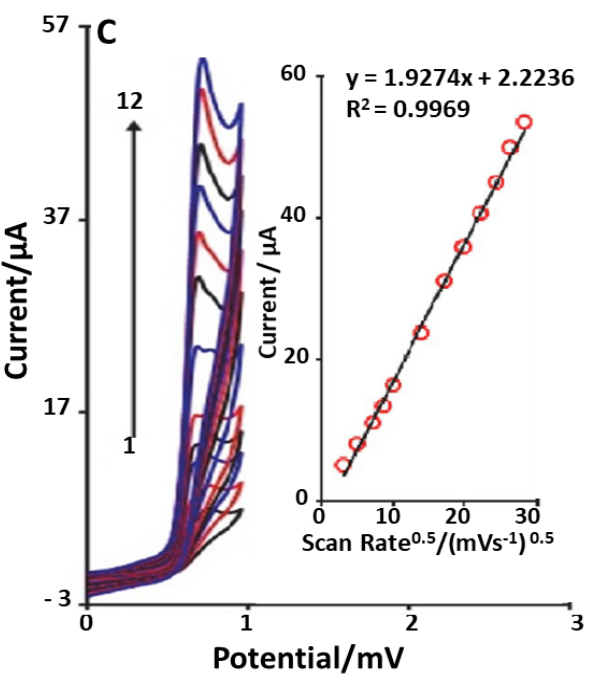

B.

Nanoparticles

Figure 8. (A): SEM Micrograph of $\mathrm{NiFe}_{2} \mathrm{O}_{4}$ and its EDX. (B): deposition of NPs on SPE with drop casting. (C): CVs of $\mathrm{NFO} / \mathrm{SPE}$ in $0.1 \mathrm{M}$ PBS (pH 7) containing $150 \mu \mathrm{M}$ of FA at various scan rates; numbers 1-12 correspond to 10, 25, 50, 75, $100,200,300,400,500,600,700$ and $800 \mathrm{mV} \mathrm{s}^{-1}$, respectively. Inset: variation of anodic peak current vs. square root of scan rate [64].

Since differential pulse voltammetry (DPV) has the advantage of having an increase in sensitivity and better characteristics for analytical applications, DPV technique was performed in order to determine various FA concentrations; a dynamic range between $1.0 \times 10^{-7}$ and $5.0 \times 10^{-4} \mathrm{M}$ and a detection limit of $3.4 \times 10^{-8} \mathrm{M}$ were found. This protocol has been applied to real samples-FA tablets and urine samples—by using standard addition method. The results for the determination are summarized in Table 8. 
Table 8. Determination of FA in FA tablet and urine samples. All the concentrations are in $\mu \mathrm{M}$ $(\mathrm{n}=5)$ [64].

\begin{tabular}{ccccc}
\hline Sample & Spiked & Found & Recovery (\%) & Rsd (\%) \\
\hline \multirow{4}{*}{ Folic acid tablet } & 0 & 15.0 & - & 3.2 \\
& 2.5 & 17.8 & 101.7 & 1.7 \\
& 5.0 & 19.5 & 97.5 & 2.8 \\
& 7.5 & 23.3 & 103.5 & 2.2 \\
Urine & 10.0 & 24.8 & 99.2 & 2.4 \\
& 0 & - & - & - \\
& 10.0 & 10.3 & 103.0 & 1.7 \\
& 20.0 & 19.9 & 99.5 & 2.3 \\
& 30.0 & 29.1 & 97.0 & 2.8 \\
\hline
\end{tabular}

Satisfactory recovery and reproducibility values of the experimental were found for FA, as demonstrated by the mean relative standard deviation (RSD\%).

\section{Conclusions}

FA has a crucial role in some extremely important biochemical processes including synthesis of nucleic acid, cell division, growth and development of fetuses. For this reason, FA supplements are widely used to prevent and handle folate deficiency in at-risk groups and also to prevent adverse events associated with antifolate medications. Due to the critical rule of FA in human health, during the past years, many efforts have been made in the analytical field in order to develop reliable and precise sensors for its determination.

In more detail, the aim of this short review is to report the most interesting and original electrochemical tools proposed in the past 5 years for FA determination in pharmaceutical preparations, food supplements and other real samples. In conclusion, all the proposed analytical platforms can be applied to the determination of FA in a plethora of real samples: human urine, blood serum, pharmaceutical or commercial preparations. Remarkable recovery values and relative standard deviations have been found in all the proposed research papers. Among all, particularly interesting is the device based on $\mathrm{Fe}_{3} \mathrm{O}_{4} @ \mathrm{SiO}_{2} / \mathrm{GR}$ nanocomposite modified graphite SPE, which shows good recovery values and $\mathrm{RSD} \%$ in the simultaneous determination of FA by means of convenient electrochemical sensor. Among traditional sensors, noteworthy is the electrochemical behavior of 2FTNE-modified CMNP paste electrodes (2FTNECMNPPE). Using SWV, the concurrent measurement of epinephrine, uric acid and FA has been realized and no significant differences between the results of the 2FTNECMNPPE and the nominal values of real samples have been observed.

Author Contributions: Conceptualization, L.M. and A.D.T.; methodology, R.C. and A.D.T.; data curation, A.D.T. and R.C.; writing-original draft preparation, A.D.T. and R.C.; writing-review and editing, L.M.; supervision, L.M.; project administration, L.M. All authors have read and agreed to the published version of the manuscript.

Funding: This research received no external funding.

Institutional Review Board Statement: Not applicable.

Informed Consent Statement: Not applicable.

Data Availability Statement: Not applicable.

Conflicts of Interest: The authors declare no conflict of interest. 


\section{References}

1. Andlid, T.A.; D'Aimmo, M.R.; Jastrebova, J. Folate and bifidobacteria. In the Bifidobacteria and Related Organisms; Elsevier: Amsterdam, The Netherlands, 2018; pp. 195-212.

2. Langston, W.C.; Darby, W.J.; Shukers, C.F.; Day, P.L. Nutritional Cytopenia (Vitamin M Deficiency) in the Monkey. J. Exp. Med. 1938, 68, 923-940. [CrossRef]

3. Talwar, G.P. Textbook of Biochemistry, Biotechnology, Allied and Molecular Medicine, 4th ed.; Place of Publication Not Identified; Prentice-Hall of India: New Delhi, India, 2015.

4. Bandžuchová, L.; Šelešovská, R.; Navrátil, T.; Chýlková, J. Electrochemical behavior of folic acid on mercury meniscus modified silver solid amalgam electrode. Electrochim. Acta 2011, 56, 2411-2419. [CrossRef]

5. Akbar, S.; Anwar, A.; Kanwal, Q. Electrochemical determination of folic acid: A short review. Anal. Biochem. 2016, 510, 98-105. [CrossRef] [PubMed]

6. Ebara, S. Nutritional role of folate. Congenit. Anom. 2017, 57, 138-141. [CrossRef] [PubMed]

7. Maynard, C.; Cummins, I.; Green, J.; Weinkove, D. A bacterial route for folic acid supplementation. BMC Biol. 2018, 16, 1-10. [CrossRef] [PubMed]

8. Gorelova, V.; Ambach, L.; Rébeillé, F.; Stove, C.; Van Der Straeten, D. Folates in Plants: Research Advances and Progress in Crop Biofortification. Front. Chem. 2017, 5, 21. [CrossRef] [PubMed]

9. Levin, I.; Giladi, M.; Altman-Price, N.; Ortenberg, R.; Mevarech, M. An alternative pathway for reduced folate biosynthesis in bacteria and halophilic archaea. Mol. Microbiol. 2004, 54, 1307-1318. [CrossRef] [PubMed]

10. Strozzi, G.P.; Mogna, L. Quantification of Folic Acid in Human Feces After Administration of Bifidobacterium Probiotic Strains. J. Clin. Gastroenterol. 2008, 42, S179-S184. [CrossRef]

11. Aufreiter, S.; Gregory, J.F.; Pfeiffer, C.M.; Fazili, Z.; Kim, Y.-I.; Marcon, N.; Kamalaporn, P.; Pencharz, P.B.; O'Connor, D.L. Folate is absorbed across the colon of adults: Evidence from cecal infusion of 13C-labeled [6S]-5-formyltetrahydrofolic acid. Am. J. Clin. Nutr. 2009, 90, 116-123. [CrossRef] [PubMed]

12. Wien, T.N.; Pike, E.; Wisløff, T.; Staff, A.; Smeland, S.; Klemp, M. Cancer risk with folic acid supplements: A systematic review and meta-analysis. BMJ Open 2012, 2, e000653. [CrossRef]

13. Berlin, N.I.; Rall, D.; Mead, J.A.R.; Freireich, E.J.; Van Scott, E.; Hertz, R.; Lipsett, M.B. Folic Acid Antagonists. Ann. Intern. Med. 1963, 59, 931-957. [CrossRef] [PubMed]

14. Mehranfar, S.; Zeinali, S.; Hosseini, R.; Mohammadian, M.; Akbarzadeh, A.; Feizi, A.H.P. History of Leukemia: Diagnosis and Treatment from Beginning to Now. Galen Med. J. 2017, 6, 2017. Available online: https://gmj.ir/index.php/gmj/article/view/702 (accessed on 12 February 2017).

15. Bronckers, I.M.G.J.; Seyger, M.M.B.; West, D.P.; Lara-Corrales, I.; Tollefson, M.; Tom, W.L.; Hogeling, M.; Belazarian, L.; Zachariae, C.; Mahé, E.; et al. Safety of Systemic Agents for the Treatment of Pediatric Psoriasis. JAMA Dermatol. 2017, 153, 1147-1157. [CrossRef]

16. Essouma, M.; Noubiap, J.J.N. Therapeutic potential of folic acid supplementation for cardiovascular disease prevention through homocysteine lowering and blockade in rheumatoid arthritis patients. Biomark. Res. 2015, 3, 1-11. [CrossRef] [PubMed]

17. Nogueira, E.; Gomes, A.C.; Preto, A.; Cavaco-Paulo, A. Folate-targeted nanoparticles for rheumatoid arthritis therapy. Nanomed. Nanotechnol. Biol. Med. 2016, 12, 1113-1126. [CrossRef] [PubMed]

18. Arnett, F.C.; Whelton, J.C.; Zizic, T.M.; Stevens, M.B. Methotrexate therapy in polymyositis. Ann. Rheum. Dis. 1973, 32, 536-546. [CrossRef] [PubMed]

19. Metzger, A.L.; Bohan, A.; Goldberg, L.S.; Bluestone, R.; Pearson, C.M. Polymyositis and Dermatomyositis: Combined Methotrexate and Corticosteroid Therapy. Ann. Intern. Med. 1974, 81, 182-189. [CrossRef] [PubMed]

20. Cobos, G.A.; Femia, A.; Vleugels, R.A. Dermatomyositis: An Update on Diagnosis and Treatment. Am. J. Clin. Dermatol. 2020, 21, 339-353. [CrossRef] [PubMed]

21. Papadopoulou, C.; Wedderburn, L.R. Treatment of Juvenile Dermatomyositis: An Update. Pediatr. Drugs 2017, 19, 423-434. [CrossRef]

22. Kim, Y.-I. Folate and colorectal cancer: An evidence-based critical review. Mol. Nutr. Food Res. 2007, 51, 267-292. [CrossRef]

23. Cole, B.F.; Baron, J.A.; Sandler, R.S.; Haile, R.W.; Ahnen, D.J.; Bresalier, R.S.; Mckeown-Eyssen, G.; Summers, R.W.; Rothstein, R.I.; Burke, C.A.; et al. Folic Acid for the Prevention of Colorectal Adenomas. JAMA 2007, 297, 2351-2359. [CrossRef] [PubMed]

24. Ebbing, M.; Bønaa, K.H.; Nygård, O.; Arnesen, E.; Ueland, P.M.; Nordrehaug, J.E.; Rasmussen, K.; Njølstad, I.; Refsum, H.; Nilsen, D.W.; et al. Cancer Incidence and Mortality After Treatment With Folic Acid and Vitamin B12. JAMA 2009, 302, $2119-2126$. [CrossRef] [PubMed]

25. Moazzen, S.; Dolatkhah, R.; Tabrizi, J.S.; Shaarbafi, J.; Alizadeh, B.Z.; De Bock, G.H.; Dastgiri, S. Folic acid intake and folate status and colorectal cancer risk: A systematic review and meta-analysis. Clin. Nutr. 2018, 37, 1926-1934. [CrossRef] [PubMed]

26. Cheung, A.; Bax, H.J.; Josephs, D.H.; Ilieva, K.M.; Pellizzari, G.; Opzoomer, J.; Bloomfield, J.; Fittall, M.; Grigoriadis, A.; Figini, M.; et al. Targeting folate receptor alpha for cancer treatment. Oncotarget 2016, 7, 52553-52574. [CrossRef]

27. Bailey, L.B.; Rampersaud, G.C.; Kauwell, G.P.A. Folic Acid Supplements and Fortification Affect the Risk for Neural Tube Defects, Vascular Disease and Cancer: Evolving Science. J. Nutr. 2003, 133, 1961S-1968S. [CrossRef] [PubMed]

28. Shlobin, N.A.; LoPresti, M.A.; Du, R.Y.; Lam, S. Folate fortification and supplementation in prevention of folate-sensitive neural tube defects: A systematic review of policy. J. Neurosurg. Pediatr. 2021, 27, 294-310. [CrossRef] [PubMed] 
29. Peng, Y.; Ou, B.-Q.; Li, H.-H.; Zhou, Z.; Mo, J.-L.; Huang, J.; Liang, F.-L. Synergistic Effect of Atorvastatin and Folic Acid on Cardiac Function and Ventricular Remodeling in Chronic Heart Failure Patients with Hyperhomocysteinemia. Med. Sci. Monit. 2018, 24, 3744-3751. [CrossRef]

30. Pieroth, R.; Paver, S.; Day, S.; Lammersfeld, C. Folate and Its Impact on Cancer Risk. Curr. Nutr. Rep. 2018, 7, 70-84. [CrossRef]

31. Herbert, V.; Zalusky, R. Interrelations of vitamin b12 and folic acid metabolism: Folic acid clearance studies. J. Clin. Investig. 1962, 41, 1263-1276. [CrossRef]

32. Quinlivan, E.; McPartlin, J.; McNulty, H.; Ward, M.; Strain, J.; Weir, D.; Scott, J. Importance of both folic acid and vitamin B12 in reduction of risk of vascular disease. Lancet 2002, 359, 227-228. [CrossRef]

33. Mason, J.B. Diet, folate, and colon cancer. Curr. Opin. Gastroenterol. 2002, 18, 229-234. [CrossRef]

34. Hirsch, S.; Sanchez, H.; Albala, C.; De La Maza, M.P.; Barrera, G.; Leiva, L.; Bunout, D. Colon cancer in Chile before and after the start of the flour fortification program with folic acid. Eur. J. Gastroenterol. Hepatol. 2009, 21, 436-439. [CrossRef] [PubMed]

35. Vora, A.; Riga, A.; Dollimore, D.; Alexander, K.S. Thermal stability of folic acid. Thermochim. Acta 2002, 392-393, 209-220. [CrossRef]

36. Nagaraja, P.; Vasantha, A.R.; Yathirajan, H.S. Spectrophotometric determination of folic acid in pharmaceutical preparations by coupling reactions with iminodibenzyl or 3-aminophenol or sodium molybdate-pyrocatechol. Anal. Biochem. 2002, 307, 316-321. [CrossRef]

37. Matias, R.; Ribeiro, P.R.S.; Sarraguça, M.; Lopes, J.A. A UV spectrophotometric method for the determination of folic acid in pharmaceutical tablets and dissolution tests. Anal. Methods 2014, 6, 3065-3071. [CrossRef]

38. Osseyi, E.S.; Wehling, R.L.; Albrecht, J.A. HPLC Determination of Stability and Distribution of Added Folic Acid and Some Endogenous Folates During Breadmaking. Cereal Chem. J. 2001, 78, 375-378. [CrossRef]

39. Jastrebova, J.; Witthöft, C.; Grahn, A.; Svensson, U.; Jägerstad, M. HPLC determination of folates in raw and processed beetroots. Food Chem. 2003, 80, 579-588. [CrossRef]

40. Bertuzzi, T.; Rastelli, S.; Mulazzi, A.; Rossi, F. LC-MS/MS Determination of Mono-Glutamate Folates and Folic Acid in Beer. Food Anal. Methods 2018, 12, 722-728. [CrossRef]

41. Sun, D.; Jin, Y.; Zhao, Q.; Tang, C.; Li, Y.; Wang, H.; Qin, Y.; Zhang, J. Modified EMR-lipid method combined with HPLC-MS/MS to determine folates in egg yolks from laying hens supplemented with different amounts of folic acid. Food Chem. 2021, 337, 127767. [CrossRef]

42. Yang, Z.; Gong, F.; Yu, Z.; Shi, D.; Liu, S.; Chen, M. Highly sensitive folic acid colorimetric sensor enabled by free-standing molecularly imprinted photonic hydrogels. Polym. Bull. 2021, 1-15, in press. [CrossRef]

43. Peng, Y.; Dong, W.; Wan, L.; Quan, X. Determination of folic acid via its quenching effect on the fluorescence of MoS2 quantum dots. Microchim. Acta 2019, 186, 605. [CrossRef]

44. Anastasopoulos, P.; Mellos, T.; Spinou, M.; Tsiaka, T.; Timotheou-Potamia, M. Chemiluminometric and Fluorimetric Determination of Folic Acid. Anal. Lett. 2007, 40, 2203-2216. [CrossRef]

45. Flores, J.R.; Peñalvo, G.C.; Mansilla, A.E.; Gómez, M.R. Capillary electrophoretic determination of methotrexate, leucovorin and folic acid in human urine. J. Chromatogr. B 2005, 819, 141-147. [CrossRef] [PubMed]

46. Zhao, S.; Yuan, H.; Xie, C.; Xiao, D. Determination of folic acid by capillary electrophoresis with chemiluminescence detection. J. Chromatogr. A 2006, 1107, 290-293. [CrossRef] [PubMed]

47. Neves, M.M.P.D.S.; González-García, M.B.; Hernández-Santos, D.; Fanjul-Bolado, P. Future trends in the market for electrochemical biosensing. Curr. Opin. Electrochem. 2018, 10, 107-111. [CrossRef]

48. Wabaidur, S.M.; Alam, S.M.; Lee, S.H.; Alothman, Z.A.; Eldesoky, G.E. Chemiluminescence determination of folic acid by a flow injection analysis assembly. Spectrochim. Acta Part A Mol. Biomol. Spectrosc. 2013, 105, 412-417. [CrossRef]

49. Batra, B.; Narwal, V.; Kalra, V.; Sharma, M.; Rana, J. Folic acid biosensors: A review. Process. Biochem. 2020, 92, 343-354. [CrossRef]

50. Mohammadi, S.Z.; Beitollahi, H.; Khodaparast, B.; Hosseinzadeh, R. Electrochemical determination of epinephrine, uric acid and folic acid using a carbon paste electrode modified with novel ferrocene derivative and core-shell magnetic nanoparticles. Res. Chem. Intermed. 2019, 45, 1117-1129. [CrossRef]

51. Lavanya, N.; Fazio, E.; Neri, F.; Bonavita, A.; Leonardi, S.; Neri, G.; Sekar, C. Electrochemical sensor for simultaneous determination of ascorbic acid, uric acid and folic acid based on $\mathrm{Mn}-\mathrm{SnO} 2$ nanoparticles modified glassy carbon electrode. J. Electroanal. Chem. 2016, 770, 23-32. [CrossRef]

52. Sadeghi, H.; Shahidi, S.-A.; Raeisi, S.N.; Ghorbani-HasanSaraei, A.; Karimi, F. Electrochemical Determination of Folic Acid in Fruit Juices Samples Using Electroanalytical Sensor Amplified with CuO/SWCNTs and 1-Butyl-2,3-dimethylimidazolium Hexafluorophosphate. Chem. Methodol. 2020, 4, 743-753. [CrossRef]

53. Mollaei, M.; Ghoreishi, S.M.; Khoobi, A. Electrochemical investigation of a novel surfactant for sensitive detection of folic acid in pharmaceutical and biological samples by multivariate optimization. Measurement 2019, 145, 300-310. [CrossRef]

54. Tahernejad-Javazmi, F.; Shabani-Nooshabadi, M.; Karimi-Maleh, H. 3D reduced graphene oxide/FeNi3-ionic liquid nanocomposite modified sensor; an electrical synergic effect for development of tert-butylhydroquinone and folic acid sensor. Compos. Part $B$ Eng. 2019, 172, 666-670. [CrossRef]

55. Karimi-Maleh, H.; Amini, F.; Akbari, A.; Shojaei, M. Amplified electrochemical sensor employing CuO/SWCNTs and 1-butyl-3methylimidazolium hexafluorophosphate for selective analysis of sulfisoxazole in the presence of folic acid. J. Colloid Interface Sci. 2017, 495, 61-67. [CrossRef] [PubMed] 
56. Jamali, T.; Karimi-Maleh, H.; Khalilzadeh, M.A. A novel nanosensor based on Pt:Co nanoalloy ionic liquid carbon paste electrode for voltammetric determination of vitamin B9 in food samples. LWT 2014, 57, 679-685. [CrossRef]

57. Rahmanpour, M.S.; Khalilzadeh, M.A. ZnO nanoparticle modified carbon paste electrode as a sensor for electrochemical determination of tert-butylhydroquinone in food samples», Anal. Bioanal. Electrochemistry 2016, 8, 922-930.

58. Aflatoonian, M.R.; Tajik, S.; Ekrami-Kakhki, M.-S.; Aflatoonian, B.; Beitollai, H. A nano-sensor based on screen printed electrode (SPE) for electro-chemical detection of vitamin B9. Eurasian Chem. Commun. 2020, 2, 609-618. [CrossRef]

59. Karimi-Maleh, H.; Hatami, M.; Moradi, R.; Khalilzadeh, M.A.; Amiri, S.; Sadeghifar, H. Synergic effect of Pt-Co nanoparticles and a dopamine derivative in a nanostructured electrochemical sensor for simultaneous determination of N-acetylcysteine, paracetamol and folic acid. Microchim. Acta 2016, 183, 2957-2964. [CrossRef]

60. Mani, V. Highly Sensitive Determination of Folic Acid Using Graphene Oxide Nanoribbon Film Modified Screen Printed Carbon Electrode. Int. J. Electrochem. Sci. 2017, 12, 475-484. [CrossRef]

61. Porada, R.; Fendrych, K.; Baś, B. Development of novel Mn-zeolite/graphite modified Screen-printed Carbon Electrode for ultrasensitive and selective determination of folic acid. Measurement 2021, 179, 109450. [CrossRef]

62. Mani, V. Determination of Folic Acid Using Graphene/Molybdenum Disulfide Nanosheets/Gold Nanoparticles Ternary Composite. Int. J. Electrochem. Sci. 2017, 258-267. [CrossRef]

63. Safaei, M.; Beitollahi, H.; Shishehbore, M.R. Simultaneous Determination of Epinephrine and Folic Acid Using the $\mathrm{Fe}_{3} \mathrm{O}_{4} @ \mathrm{SiO}_{2} / \mathrm{GR}$ Nanocomposite Modified Graphite. Russ. J. Electrochem. 2018, 54, 851-859. [CrossRef]

64. Safaei, M.; Beitollahi, H.; Shishehbore, M.R. Modified Screen Printed Electrode for Selective Determination of Folic Acid. Acta Chim. Slov. 2019, 66, 777-783. [CrossRef]

65. Gross, R.L.; Reid, J.V.; Newberne, P.M.; Burgess, B.; Marston, R.; Hift, W. Depressed cell-mediated immunity in megaloblastic anemia due to folic acid deficiency. Am. J. Clin. Nutr. 1975, 28, 225-232. [CrossRef] [PubMed]

66. Cinková, K.; Švorc, L'.; Šatkovská, P.; Vojs, M.; Michniak, P.; Marton, M. Simple and Rapid Quantification of Folic Acid in Pharmaceutical Tablets Using a Cathodically Pretreated Highly Boron-doped Polycrystalline Diamond Electrode. Anal. Lett. 2015, 49, 107-121. [CrossRef]

67. Keeley, G.P.; O’Neill, A.; Holzinger, M.; Cosnier, S.; Coleman, J.N.; Duesberg, G.S. DMF-exfoliated graphene for electrochemical NADH detection. Phys. Chem. Chem. Phys. 2011, 13, 7747-7750. [CrossRef] [PubMed] 